\title{
Enhanced Photovoltaic Properties of Perovskite Solar Cells by Employing Bathocuproine/Hydrophobic Polymer Films as Hole-Blocking/Electron-Transporting Interfacial Layers
}

\author{
Guan-Zhi Liu ${ }^{1}$, Chi-Shiuan Du ${ }^{1}$, Jeng-Yue Wu ${ }^{1}$, Bo-Tau Liu ${ }^{2, * \mathbb{D}}$, Tzong-Ming Wu ${ }^{3}$ (D), Chih-Feng Huang ${ }^{1}(\mathbb{D}$ and \\ Rong-Ho Lee ${ }^{1, *(\mathbb{D})}$
}

check for

updates

Citation: Liu, G.-Z.; Du, C.-S.; Wu, J.-Y.; Liu, B.-T.; Wu, T.-M.; Huang, C.-F.; Lee, R.-H. Enhanced Photovoltaic Properties of Perovskite Solar Cells by Employing Bathocuproine/ Hydrophobic Polymer Films as Hole-Blocking/Electron-Transporting Interfacial Layers. Polymers 2021, 13, 42. https://dx.doi.org/10.3390/ polym13010042

Received: 26 November 2020 Accepted: 22 December 2020 Published: 24 December 2020

Publisher's Note: MDPI stays neutral with regard to jurisdictional claims in published maps and institutional affiliations.

Copyright: (c) 2020 by the authors. Licensee MDPI, Basel, Switzerland. This article is an open access article distributed under the terms and conditions of the Creative Commons Attribution (CC BY) license (https: / / creativecommons.org/ licenses/by/4.0/).
1 Department of Chemical Engineering, National Chung Hsing University, Taichung 402, Taiwan; as798320@gmail.com (G.-Z.L.); justduit0831@gmail.com (C.-S.D.); s0916871303@gmail.com (J.-Y.W.); HuangCF@dragon.nchu.edu.tw (C.-F.H.)

2 Department of Chemical and Materials Engineering, National Yunlin University of Science and Technology, Yunlin 64002, Taiwan

3 Department of Materials Science and Engineering, National Chung Hsing University, Taichung 402, Taiwan; tmwu@nchu.edu.tw

* Correspondence: liubo@yuntech.edu.tw (B.-T.L.); rhl@dragon.nchu.edu.tw (R.-H.L.); Tel.: +886-5-5342601 (B.-T.L.); +886-4-22854308 (R.-H.L.); Fax: +886-5-5321719 (B.-T.L.); +886-4-22854734 (R.-H.L.)

\begin{abstract}
In this study, we improved the photovoltaic (PV) properties and storage stabilities of inverted perovskite solar cells (PVSCs) based on methylammonium lead iodide $\left(\mathrm{MAPbI}_{3}\right)$ by employing bathocuproine (BCP)/poly(methyl methacrylate) (PMMA) and BCP/polyvinylpyrrolidone (PVP) as hole-blocking and electron-transporting interfacial layers. The architecture of the PVSCs was indium tin oxide/poly(3,4-ethylenedioxythiophene):polystyrenesulfonate $/ \mathrm{MAPbI}_{3} /[6,6]$-phenyl$\mathrm{C}_{61}$-butyric acid methyl ester/BCP based interfacial layer/Ag. The presence of PMMA and PVP affected the morphological stability of the $\mathrm{BCP}$ and $\mathrm{MAPbI}_{3}$ layers. The storage-stability of the $\mathrm{BCP} / \mathrm{PMMA}$-based PVSCs was enhanced significantly relative to that of the corresponding unmodified BCP-based PVSC. Moreover, the PV performance of the BCP/PVP-based PVSCs was enhanced when compared with that of the unmodified BCP-based PVSC. Thus, incorporating hydrophobic polymers into BCP-based hole-blocking/electron-transporting interfacial layers can improve the PV performance and storage stability of PVSCs.
\end{abstract}

Keywords: bathocuproine; methylammonium lead iodide; electron-transporting interfacial layer; perovskite solar cells

\section{Introduction}

Organometal halide perovskites, particularly methylammonium lead iodide $\left(\mathrm{CH}_{3} \mathrm{NH}_{3} \mathrm{PbI}_{3}\right.$, $\left.\mathrm{MAPbI}_{3}\right)$ and methylammonium lead bromide $\left(\mathrm{CH}_{3} \mathrm{NH}_{3} \mathrm{PbBr}_{3}, \mathrm{MAPbBr}_{3}\right)$, are highly suitable for use in solar cells because of their excellent photovoltaic (PV) properties (large absorption coefficients in the Vis to near-infrared (NIR) region, long diffusion lengths of charge carriers, excellent charge mobility, and high photoconversion efficiencies (PCEs)) [1-6]. Perovskite solar cells (PVSCs), having planar or mesoscopic structures, can be fabricated through solution processing with thermal treatment at low temperatures [6-8]. Many efforts have been made to improve the PV properties of PVSCs; for example, by designing new perovskite materials with high photo-electron conversion [9,10], interfacial engineering between the perovskite layer and the electron- or hole-transporting layer (ETL or HTL) [11-14], controlling the crystal growth of the perovskite [15-20], and adding suitable amounts of halide, cationic, organic, and polymer additives in the perovskite layer [21-29].

In addition to a high PCE, a PVSC must possess high operational stability if it is to find wide applicability $[26,30]$. Incorporating an inorganic material $[27,28]$ or hydrophobic 
polymer under the cathode layer can be an effective method to protect the PVSC from the permeation of oxygen and humidity [29]. For example, hydrophobic poly(methyl methacrylate) (PMMA) has been incorporated into PVSCs to enhance their operational and storage stabilities [30-33]. Kundu et al. reported a PVSC featuring an HTL comprising of poly(3-hexylthiophene) (P3HT) and PMMA; the PMMA matrix imparted good resistance to the permeation of moisture, resulting in a large enhancement of the stability of the cell [30]. Habisreutinger et al. found that depositing PMMA on top of a P3HT/single-walled carbon nanotube (SWNT) nanohybrid-based HTL filled the voids within the P3HT/SWNT nanohybrid and blocked the contact of the Ag-based cathode with the $\mathrm{MAPbI}_{3}$ layer; incorporating the PMMA layer enhanced the shunt resistance, open-circuit voltage ( $\left.V_{\mathrm{OC}}\right)$, and fill factor (FF) of the PVSC, while also inhibiting the permeation of moisture into the $\mathrm{MAPbI}_{3}$ layer and increasing the storage stability [32]. Furthermore, adding PMMA into two-dimensional layered $\mathrm{MAPbI}_{3}$ intermediates has led to self-assembly into threedimensional perovskite crystal grains featuring a coating of PMMA at the crystal grain boundaries; this bilayer structure inhibited the permeation of moisture and enhanced the stability of $\mathrm{MAPbI}_{3}$ [33]. Moreover, the presence of a PMMA film can decrease the trap density by compensating electronically for iodide vacancies along the boundary; this approach can minimize charge recombination and improve the values of $V_{\mathrm{OC}}$ of PVSCs [33].

In addition to PMMA, the hydrophobic polymer polyvinylpyrrolidone (PVP) has also been used as an interfacial material between the ETL and the cathode to improve PV performance. The quality of the ETL-cathode interface can have a dramatic effect on the electron transport and extraction in the PVSC. Incorporating PVP has promoted electron transport across the perovskite-cathode interface when using a [6,6]-phenyl- $\mathrm{C}_{61}$-butyric acid methyl ester $\left(\mathrm{PC}_{61} \mathrm{BM}\right)$-based ETL. Moreover, the presence of a dipole layer after the addition of PVP can enhance the built-in potential across the cell, thereby favoring charge transport from the ETL to the cathode and improving the PV properties [34]. In addition, hydrophobic PVP has been used as an additive in the perovskite layer to improve PV performance by protecting the perovskite crystals from the damaging effects of moisture; the acylamino groups of PVP enhanced the electron density at the perovskite surface and, thereby, decreased the surface energy and stabilized the perovskite layer; the resulting PVSC displayed a high PCE and excellent moisture-stability [35]. Furthermore, strong interactions between $\mathrm{Pb}(\mathrm{II})$ ions and the $\mathrm{C}=\mathrm{O}$ groups in $\mathrm{PVP}$ can lead to the nuclei distributing uniformly along the PVP chains, resulting in compact $\mathrm{MAPbI}_{3}$ films; consequently, PVPadded perovskite layers can possess crystalline structures that enhance the PCE-stability of their PVSCs [36-39].

In inverted PVSCs, the fullerene derivative $\mathrm{PC}_{61} \mathrm{BM}$ is usually employed as an electron extraction layer and ETL at the perovskite-cathode interface. Introducing a bathocuproine (BCP)-based hole-blocking/electron-transporting interfacial layer between the $\mathrm{PC}_{61} \mathrm{BM}$ layer and the cathode can enhance a PVSC's FF and short-circuit current density $\left(J_{S C}\right)$ by filling voids and improving the surface morphology of the $\mathrm{PC}_{61} \mathrm{BM}$ layer $[6,40]$. The polar functional groups of $\mathrm{BCP}$ can enhance the value of $V_{\mathrm{OC}}$ of a PVSC by effectively enhancing its built-in potential [41]. Moreover, the presence of $\mathrm{BCP}$ prevents $\mathrm{Ag}$ atoms from diffusing from the cathode to the $\mathrm{MAPbI}_{3}$ layer, thereby enhancing the operational stability of the PVSCs [42]. In this present study, we measured the PV properties and storage stabilities of $\mathrm{MAPbI}_{3}$-based inverted PVSCs incorporating $\mathrm{BCP} / \mathrm{PMMA}$ and $\mathrm{BCP} / \mathrm{PVP}$ composites as their hole-blocking/electron-transporting interfacial layers. The architecture of our PVSCs (Figure 1) was indium tin oxide (ITO)/poly(3,4ethylenedioxythiophene):polystyrenesulfonate (PEDOT:PSS) $/ \mathrm{MAPbI}_{3} / \mathrm{PC}_{61} \mathrm{BM} / \mathrm{BCP}$ based interfacial layer / Ag. Incorporating PMMA into the $\mathrm{BCP}$ layer enhanced the storage stability of our PVSC, while PVP in the BCP layer facilitated electron transport at the perovskitecathode interface. We used scanning electron microscopy (SEM) and X-ray diffractometry (XRD) to examine the morphologies and crystal structures of the resulting perovskite layers, and atomic force microscopy (AFM) to observe the morphologies of the BCP/PMMA and $\mathrm{BCP} / \mathrm{PVP}$ layers. The hydrophobicity/hydrophilicity of the BCP/PMMA and BCP/PVP 
layers were determined using a contact angle (CA) meter. We found that the BCP/PMMA and BCP/PVP interfacial layers enhanced the PV properties, the PCEs, and the storage stabilities of their $\mathrm{MAPbI}_{3}$-based PVSCs.
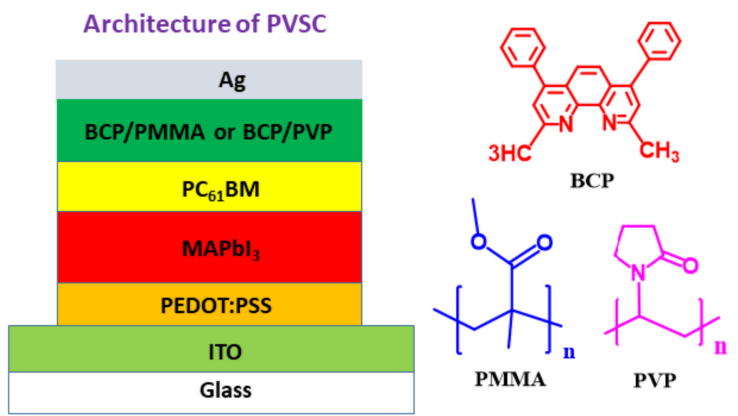

Figure 1. Architecture of the inverted perovskite solar cells (PVSCs).

\section{Experimental Details}

\subsection{Materials and Instrumentation}

Methylamine $\left(\mathrm{CH}_{3} \mathrm{NH}_{2}\right)$, lead iodide $\left(\mathrm{PbI}_{2}\right), \mathrm{BCP}, \mathrm{PMMA}\left(\mathrm{M}_{\mathrm{w}}=15,000\right)$, and PVP $\left(M_{\mathrm{W}}=10,000\right)$ were purchased from Sigma-Aldrich (St. Louis, MO, USA), Acros, (Fukuoka, Japan) and TCI Chemical (Tokyo, Japan), and used without purification. $\mathrm{PC}_{61} \mathrm{BM}_{\text {was }}$ purchased from NANO-C (Beijing, China). Isopropanol, $\gamma$-butyrolactone (GBL), dimethylsulfoxide (DMSO), toluene, and $o$-dichlorobenzene (o-DCB) were distilled over appropriate drying agents prior to use.

Fourier transform infrared (FTIR) spectra were recorded using a HORIBA FT-720 FTIR spectrometer (HORIBA Inc., Tainan City, Taiwan). Differential scanning calorimetry (DSC2010, TA Instruments, New Castle, DE, USA) was used to determine the glass transition temperatures $\left(T_{\mathrm{g}}\right)$ of the $\mathrm{BCP} / \mathrm{PMMA}$ and $\mathrm{BCP} / \mathrm{PVP}$ blend films under a $\mathrm{N}_{2}$ atmosphere (scanning rate: $10{ }^{\circ} \mathrm{C} \mathrm{min}^{-1}$ ). UV-Vis absorption spectra were recorded using a Hitachi U3010 UV-Vis spectrometer (Hitachi High-Tech Co., Tokyo, Japan). Photoluminescence (PL) spectra were recorded using a Hitachi F-4500 fluorescence spectrophotometer. AFM images of $\mathrm{BCP} / \mathrm{PMMA}$ and $\mathrm{BCP} / \mathrm{PVP}$ blend films coating the surface of the ETL $\left(\mathrm{PC}{ }_{61} \mathrm{BM}\right)$ were recorded using a Seiko SII SPA400 (Chiba, Japan) atomic force microscope operated in tapping mode. Cold field emission scanning electron microscopy (FESEM) images of the $\mathrm{MAPbI}_{3}$ layer were recorded using a Hitachi S-4800 microscope (Integrated Service Tech. Inc., Hinchu, Taiwan). Powder XRD of the perovskite layer was measured using a Shimadzu SD-D1 instrument (Shimadzu Scientific Instrument Co., Taipei, Taiwan) and a Cu target. The CAs of water droplets on the BCP/PMMA and BCP/PVP films were determined using a Kyowa Drop Master optical CA meter (Applied Trentech Inc., Taipei, Taiwan).

\subsection{Fabrication and Characterization of PVSCS}

The architecture of the PVSCs was ITO-coated glass/PEDOT:PSS/MAPbI $/ \mathrm{PC}_{61} \mathrm{BM} /$ BCP:PMMA or BCP:PVP/Ag $(100 \mathrm{~nm})$. The photoactive area of each device was $0.24 \mathrm{~cm}^{2}$. ITO-coated glass, having a sheet resistance of $20 \Omega$ square $^{-1}$, was obtained from Luminescence Tech (New Taipei City, Taiwan); $\mathrm{PC}_{61} \mathrm{BM}$ was procured from Nanocarbon (Beijing, China). The glass substrates featuring patterned ITO electrodes were washed well and then cleaned using $\mathrm{O}_{2}$ plasma. PEDOT:PSS (AI4083, Heraeus Clevios Co., Hanau, Germany) was spin-coated onto the ITO layer. The sample was heated at $110{ }^{\circ} \mathrm{C}$ for $30 \mathrm{~min}$. Methylammonium iodide (MAI; $0.200 \mathrm{~g}, 1.25 \mathrm{mmol})$ and $\mathrm{PbI}_{2}(0.580 \mathrm{~g}, 1.25 \mathrm{mmol})$ were stirred in a mixture of GBL and DMSO $(1: 1, v / v ; 1 \mathrm{~mL})$ to obtain a $\mathrm{MAPbI}_{3}$ solution. The $\mathrm{MAPbI}_{3}$ solution $(0.2 \mathrm{~mL})$ was deposited on the surface of the PEDOT:PSS layer through two consecutive spin-coating processes at 1000 and $3000 \mathrm{rpm}$ for 10 and $30 \mathrm{~s}$, respectively. During the second spin-coating process, toluene $(0.5 \mathrm{~mL})$ was drop-cast onto the substrate, which was then dried on a hot plate $\left(80{ }^{\circ} \mathrm{C}, 5 \mathrm{~min}\right)$. A solution $(0.2 \mathrm{~mL})$ of $\mathrm{PC}_{61} \mathrm{BM}(20 \mathrm{mg}$ $\left.\mathrm{mL}^{-1}\right)$ in $o$-DCB was coated on top of the $\mathrm{MAPbI}_{3}$ layer; a solution $(0.3 \mathrm{~mL})$ of BCP or 
a BCP/polymer (PMMA or PVP) blend in isopropanol $\left(0.5 \mathrm{mg} \mathrm{mL}^{-1}\right)$ was then coated on the $\mathrm{PC}_{61} \mathrm{BM}$ layer. The $\mathrm{Ag}$ cathode was thermally deposited onto the $\mathrm{BCP} / \mathrm{PMMA}$ or $\mathrm{BCP} / \mathrm{PVP}$ layer under high vacuum. The PV parameters of the PVSCs were determined using a programmable electrometer (Keithley 2400, Keithley Instruments, Inc., Cleveland, $\mathrm{OH}$, USA) under illumination with AM1.5 light from a solar simulator (NewPort Oriel 96000, Newport Corporation, Taipei, Taiwan) at an intensity of $100 \mathrm{~mW} \mathrm{~cm}^{-2}$.

\section{Results and Discussion}

\subsection{Chemical Structures and Thermal Properties of BCP/PMMA and BCP/PVP Blends}

The functional groups in the $\mathrm{BCP} / \mathrm{PMMA}$ and $\mathrm{BCP} / \mathrm{PVP}$ blends were characterized using FTIR spectroscopy. FTIR spectra of BCP, PMMA, PVP, BCP/PMMA $(5: 1, w / w)$, and $\mathrm{BCP} / \mathrm{PVP}(5: 1, w / w)$ are provided in Figure 2. In the spectra of BCP, PMMA, and PVP, the signals for $\mathrm{C}-\mathrm{H}$ stretching appeared in the range $2300-3200 \mathrm{~cm}^{-1}$ and those for $\mathrm{C}-\mathrm{H}$ bending in the $\mathrm{CH}_{3}$ and $\mathrm{CH}_{2}$ units at $1450-1600 \mathrm{~cm}^{-1}$. In the spectrum of $\mathrm{BCP}$, the signal for $=\mathrm{C}-\mathrm{H}$ bending of the aromatic ring appeared at $707 \mathrm{~cm}^{-1}$; the signal of the imino $(\mathrm{C}=\mathrm{N})$ group appeared at $1716 \mathrm{~cm}^{-1}$; and the signals for $\mathrm{C}=\mathrm{C}$ stretching in the aromatic ring appeared at 1488 and $1569 \mathrm{~cm}^{-1}$. In the spectra of PMMA and PVP, the signals for $\mathrm{C}=\mathrm{O}$ stretching appeared at 1733 and $1656 \mathrm{~cm}^{-1}$, respectively; for PMMA, the signals for the C-O moieties of the ester groups appeared at 1147 and $1193 \mathrm{~cm}^{-1}$; for PVP, the signal for C-N stretching appeared at $1290 \mathrm{~cm}^{-1}$. Furthermore, the signals of BCP, PMMA, and PVP appeared in the spectra of the $\mathrm{BCP} / \mathrm{PMMA}$ and $\mathrm{BCP} / \mathrm{PVP}$ blends.

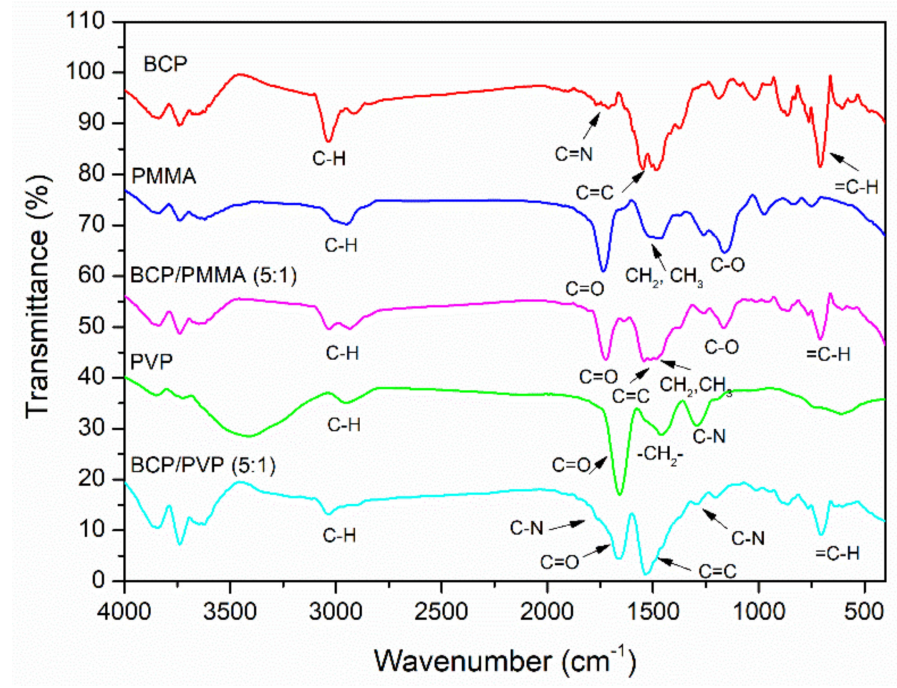

Figure 2. FTIR (Fourier transform infrared) spectra of bathocuproine (BCP), poly(methyl methacrylate) (PMMA), polyvinylpyrrolidone (PVP), BCP/PMMA $(5: 1, w / w)$, and $\mathrm{BCP} / \mathrm{PVP}(5: 1, w / w)$.

Figure 3 displays DSC thermograms of BCP, BCP/PMMA (5:1, w/w), and BCP/PVP (5:1, w/w). The values of $T_{\mathrm{m}}$ for BCP, BCP/PMMA, and BCP/PVP samples were 289, 279, and $283{ }^{\circ} \mathrm{C}$, respectively. The lower value of $T_{\mathrm{m}}$ of the $\mathrm{BCP} / \mathrm{PMMA}$ blend implies that its miscibility was greater than that of the $\mathrm{BCP} / \mathrm{PVP}$ blend.

\subsection{Optical Properties of $M A P b I_{3}$ Perouskite Film}

We recorded UV-Vis absorption and photoluminescence (PL) spectra to examine the optical properties of the $\mathrm{MAPbI}_{3}$ layer (Figure S1). The absorption onset of the $\mathrm{MAPbI}_{3}$ layer (ca. $780 \mathrm{~nm}$ ) suggested an optical band gap of $1.6 \mathrm{eV}$ [43]. The maximal PL wavelength of the $\mathrm{MAPbI}_{3}$ layer appeared near $768 \mathrm{~nm}$, when excited at a wavelength of $510 \mathrm{~nm}$ [44]. 


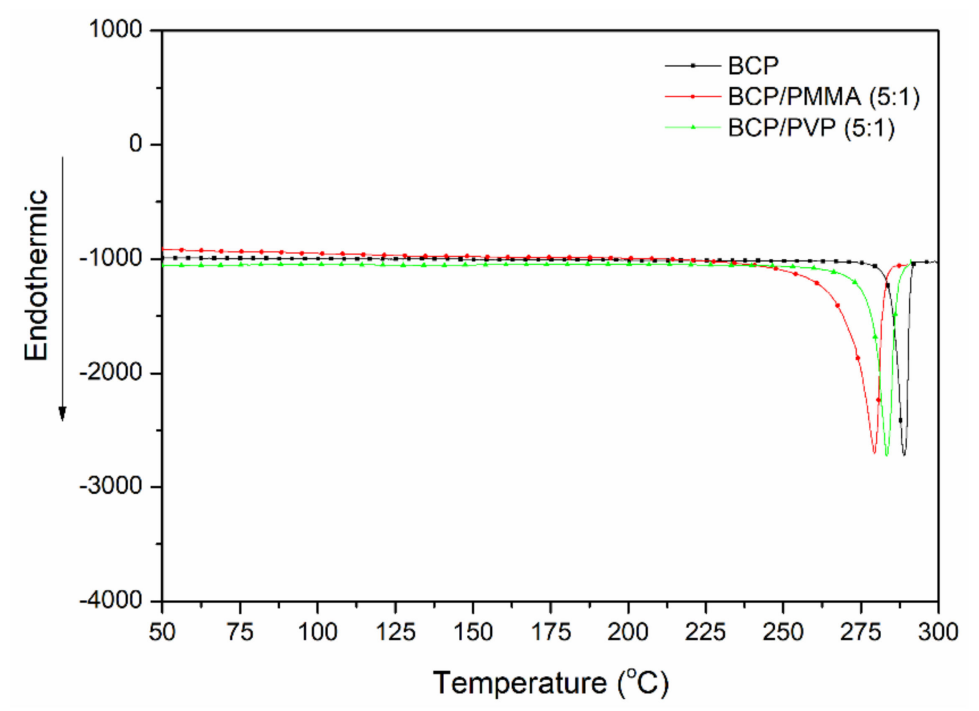

Figure 3. DSC (differential scanning calorimetry) thermograms of $\mathrm{BCP}, \mathrm{BCP} / \mathrm{PMMA}(5: 1, w / w)$, and $\operatorname{BCP} / \operatorname{PVP}(5: 1, w / w)$.

\subsection{SEM Images of $\mathrm{MAPbI}_{3}$ Layers Coated with Various Electron-Transporting Interfacial Films}

Figure 4 presents SEM images of the $\mathrm{MAPbI}_{3}$ perovskite film. In addition to the presence of grain boundaries between crystals, the crystal grains were distributed uniformly in the $\mathrm{MAPbI}_{3}$ perovskite film, without other defects. The largest crystal grain had a size of approximately $210 \mathrm{~nm}$. Such a high-quality $\mathrm{MAPbI}_{3}$ layer is generally favorable for PVSCs displaying high PV performance. Figure 5 displays cross-sectional SEM images of ITO/PEDOT:PSS $/ \mathrm{MAPbI}_{3} / \mathrm{PC}_{61} \mathrm{BM}$ structures coated with electron-transporting interfacial layers of $\mathrm{BCP}, \mathrm{BCP} / \mathrm{PMMA}$, and $\mathrm{BCP} / \mathrm{PVP}$ films. The thicknesses of the $\mathrm{MAPbI}_{3}$ layers ranged from 275.6 to $290.6 \mathrm{~nm}$. We suspected that the dense packing of the grain crystals of the $\mathrm{MAPbI}_{3}$ layer would minimize grain boundary defects and enhance the charge transfer capacity. These $\mathrm{MAPbI}_{3}$-based photoenergy conversion layers possessed good film quality. In addition, the thicknesses of the $\mathrm{PC}_{61} \mathrm{BM} / \mathrm{BCP} /$ polymer (PMMA or PVP) structures ranged from 275.6 to $290.6 \mathrm{~nm}$. These SEM images revealed that the $\mathrm{BCP} /$ polymer composites filled the voids in the $\mathrm{PC}_{61} \mathrm{BM}$ layer during the spin-coating process. Therefore, only a single layer containing $\mathrm{PC}_{61} \mathrm{BM}$ and the $\mathrm{BCP} /$ polymer composite appeared on the surface of the $\mathrm{MAPbI}_{3}$ layer. The good passivation of the $\mathrm{BCP} /$ polymer composite on the $\mathrm{PC}_{61} \mathrm{BM}$ layer would potentially facilitate electron transport from $\mathrm{PC}_{61} \mathrm{BM}$ to the cathode.

\subsection{XRD Images of $\mathrm{MAPbI}_{3}$ Perovskite Films Coated with Various Hole-Blocking/Electron-Transporting Interfacial Films}

To investigate the effect of the hole-blocking/electron-transporting interfacial layers on the storage-stability of the $\mathrm{MAPbI}_{3}$ film, we used XRD to study the crystal structures of the $\mathrm{MAPbI}_{3}$ films after storage at $30{ }^{\circ} \mathrm{C}$ and $35 \%$ relative humidity for 10 days. Figure 6 presents the XRD patterns of the ITO/PEDOT:PSS $/ \mathrm{MAPbI}_{3} / \mathrm{PC}_{61} \mathrm{BM}$ structures coated with electron-transporting interfacial layers of $\mathrm{BCP}, \mathrm{BCP} / \mathrm{PMMA}(5: 1, w / w)$, and $\mathrm{BCP} / \mathrm{PVP}$ $(5: 1, w / w)$. The patterns of the $\mathrm{MAPbI}_{3}$ films featured diffraction peaks at 14.2, 28.4, and $31.6^{\circ}$, corresponding to the (110), (220), and (310) phases, respectively [45,46], suggesting tetragonal perovskite structures having lattice constants $a$ and $b$ of $8.883 \AA$ and $c$ of $12.677 \AA$ [45]. Figure 6a reveals that $\mathrm{MAPbI}_{3}$ dissociated partially into $\mathrm{MAI}$ and $\mathrm{PbI}_{2}$ after storage under the ambient conditions for 10 days, with a diffraction peak for $\mathrm{PbI}_{2}$ appearing at $13^{\circ}$ [45]. For the $\mathrm{MAPbI}_{3}$ film coated with the $\mathrm{BCP} / \mathrm{PMMA}$ blend film, the intensity of this diffraction peak at $13^{\circ}$ was suppressed significantly relative to that of the $\mathrm{MAPbI}_{3}$ coated with BCP (Figure 6b). Thus, the addition of PMMA in the BCP layer inhibited the permeation of moisture into the $\mathrm{MAPbI}_{3}$ layer to prevent its dissociation. In contrast, when compared with the $\mathrm{MAPbI}_{3}$ film coated with the layer of $\mathrm{BCP}$, the intensity of the $\mathrm{PbI}_{2}$ 
diffraction peak at $13^{\circ}$ was higher for the $\mathrm{MAPbI}_{3}$ film coated with the $\mathrm{BCP} / \mathrm{PVP}$ blend film after storage under ambient conditions for 5 and 10 days (Figure 6c). Thus, the $\mathrm{MAPbI}_{3}$ film coated with the BCP/PVP blend film was not resistant toward the permeation of moisture, suggesting poor compatibility between $\mathrm{BCP}$ and PVP. Moreover, the crystal sizes of the $\mathrm{MAPbI}_{3}$ films coated with BCP, BCP /PMMA, and BCP/PVP layers after storage at $30{ }^{\circ} \mathrm{C}$ and $35 \%$ relative humidity for 0,5 , and 10 days are summarized in Table S1. The crystal sizes of the $\mathrm{MAPbI}_{3}$ films decreased as the storage time increased, which corresponded to the degradation of the perovskite crystals. Moisture entering $\mathrm{MAPbI}_{3}$ caused the decreased crystals sizes.
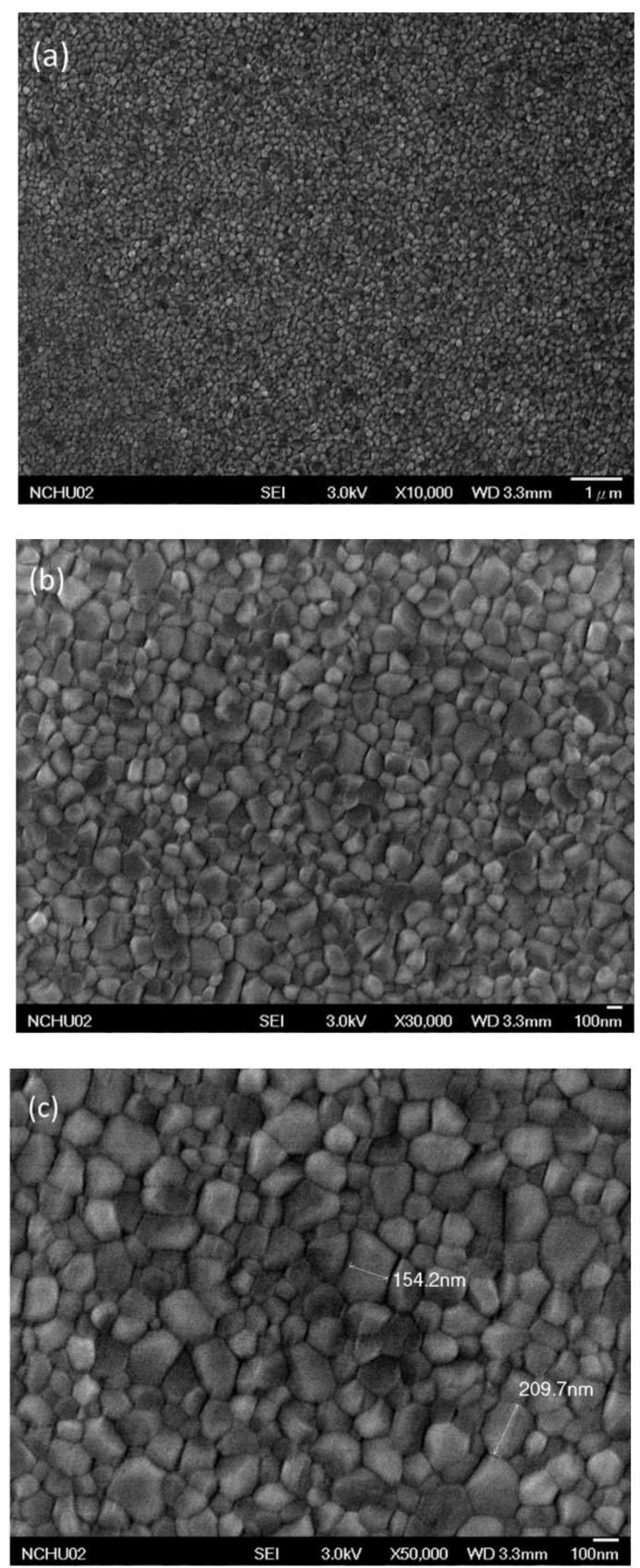

Figure 4. SEM (scanning electron microscopy) images $[(\mathbf{a}) \times 10,000 ;(\mathbf{b}) \times 30,000 ;(\mathbf{c}) \times 50,000]$ of a $\mathrm{MAPbI}_{3}$ perovskite film coated on the HTL, recorded after thermal annealing $\left(80^{\circ} \mathrm{C}, 5 \mathrm{~min}\right)$. 


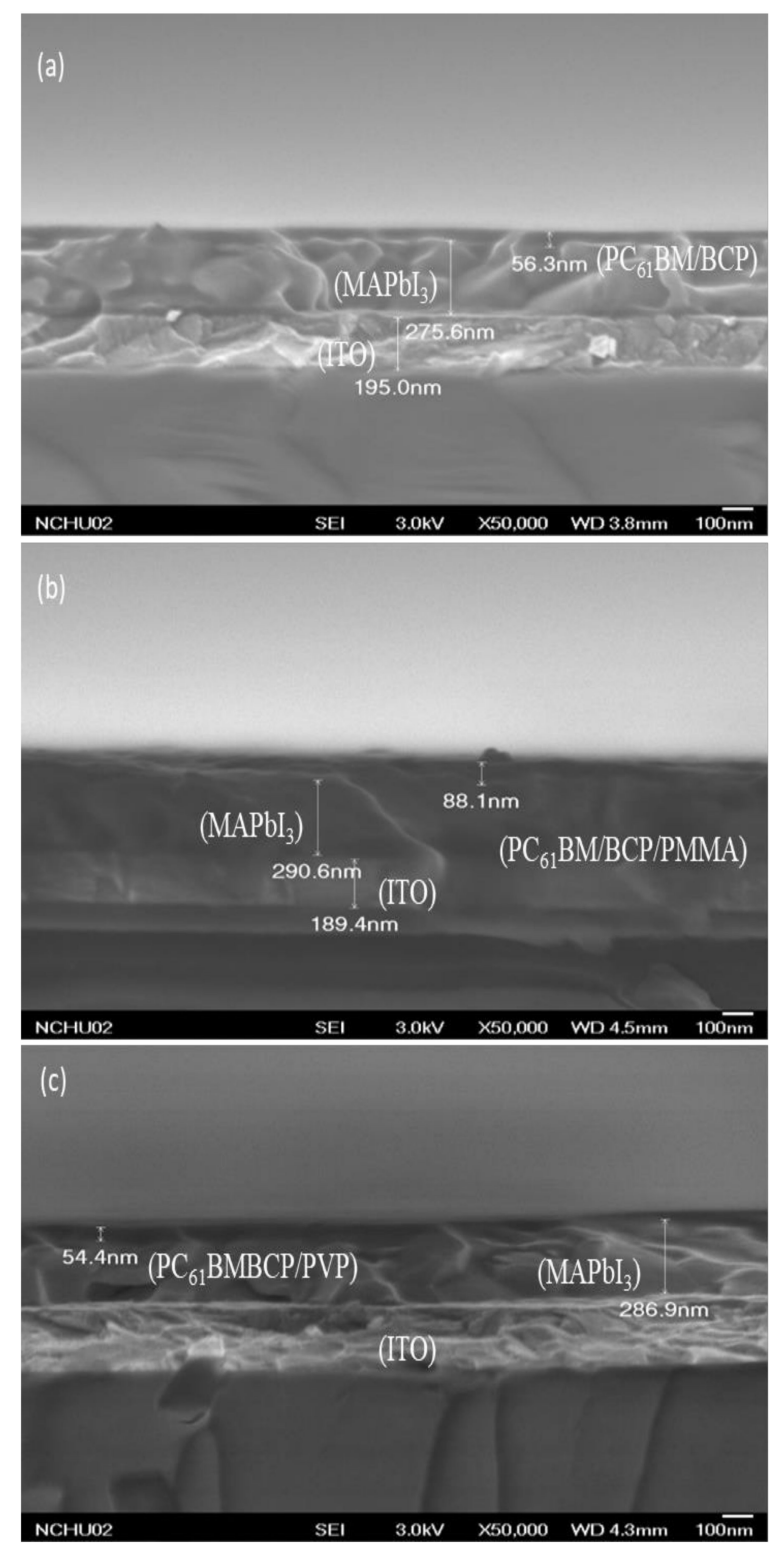

Figure 5. Cross-sectional SEM images of ITO/PEDOT:PSS/ $\mathrm{MAPbI}_{3} / \mathrm{PC}_{61} \mathrm{BM}$ structures coated with hole-blocking/electron-transporting interfacial layers of (a) BCP, (b) BCP/PMMA (5:1, w/w), and (c) $\mathrm{BCP} / \mathrm{PVP}(5: 1, w / w)$, recorded after thermal annealing $\left(80^{\circ} \mathrm{C}, 5 \mathrm{~min}\right)$.

\subsection{AFM Images and $C A$ s of $B C P / P M M A$ and $B C P / P V P$ Composite Films}

We used AFM to study the surface morphologies of the BCP/PMMA and BCP/PVP hole-blocking/electron-transporting interfacial layers. Figures S2 and S3 display topographic and phase images of films of $\mathrm{BCP}$ and the $\mathrm{BCP} / \mathrm{PMMA}$ and $\mathrm{BCP} / \mathrm{PVP}$ composites, recorded after thermal treatment at $80{ }^{\circ} \mathrm{C}$ for $5 \mathrm{~min}$. Table $\mathrm{S} 1$ summarizes the surface roughness of these $\mathrm{BCP}, \mathrm{BCP} / \mathrm{PMMA}$, and $\mathrm{BCP} / \mathrm{PVP}$ films. The topographic images in Figure $\mathrm{S} 2$ reveal that the surface roughness of the $\mathrm{BCP}$ films was not enhanced after the addition of PMMA. No phase separation was evident in the phase images of the composite films. Thus, BCP and PMMA exhibited good compatibility. In contrast, significant phase separation was evident in the phase images of the BCP/PVP composite films (Figure S3), suggesting poor compatibility between $\mathrm{BCP}$ and PVP. Nevertheless, the surface roughness of the $\mathrm{BCP} / \mathrm{PVP}$ films were not higher than those of the $\mathrm{BCP} / \mathrm{PMMA}$ films. 

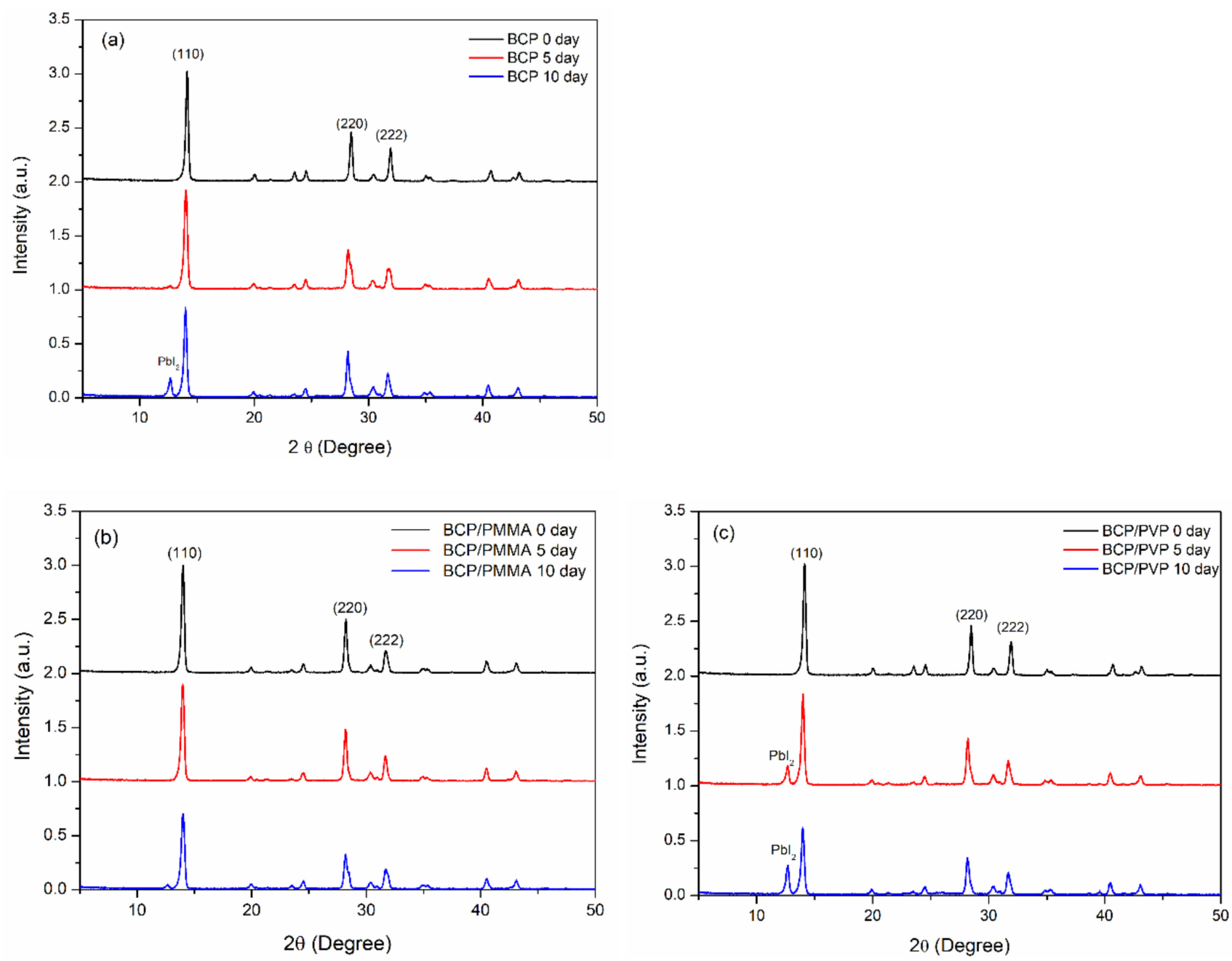

Figure 6. XRD (X-ray diffractometry) patterns of ITO/PEDOT:PSS/MAPbI $3 / \mathrm{PC}_{61} \mathrm{BM}$ structures coated with holeblocking/electron-transporting interfacial layers of (a) BCP, (b) BCP/PMMA (5:1, w/w), and (c) BCP/PVP (5:1, w/w), recorded after storage at $30{ }^{\circ} \mathrm{C}$ and $35 \%$ relative humidity for 0,5 , and 10 days.

We also used AFM to determine the stability of the surface morphologies of the films of $\mathrm{BCP}$ and the BCP/PMMA and BCP/PVP composites. Figures 7-9 display AFM images of the $\mathrm{BCP}, \mathrm{BCP} / \mathrm{PMMA}(5: 1, w / w)$, and $\mathrm{BCP} / \mathrm{PVP}(5: 1, w / w)$ films, respectively, after storage at $30{ }^{\circ} \mathrm{C}$ and $35 \%$ relative humidity for 0,5 , and 10 days. The morphology of $\mathrm{BCP}$ film was modified only slightly after storage for 5 days, but it changed significantly after 10 days (Figure 7). The morphology of the BCP/PMMA film (Figure 8) had changed only slightly after storage for 10 days, consistent with the good compatibility of BCP and PMMA. In other words, the BCP/PMMA film had high morphological stability. In contrast, the stability of the morphology of the $\mathrm{BCP} / \mathrm{PVP}$ film was much poorer than those of the $\mathrm{BCP}$ film (Figure 9). Some of the BCP had separated from the BCP/PVP film, leading to the formation of $\mathrm{BCP}$-based crystals after storage for 5 days, with a higher density appearing after storage for 10 days. Unlike the $\mathrm{BCP}$ and $\mathrm{BCP} / \mathrm{PMMA}$ films, the surface roughness of the $\mathrm{BCP} / \mathrm{PVP}$ film was enhanced significantly upon increasing the storage time under ambient conditions. 

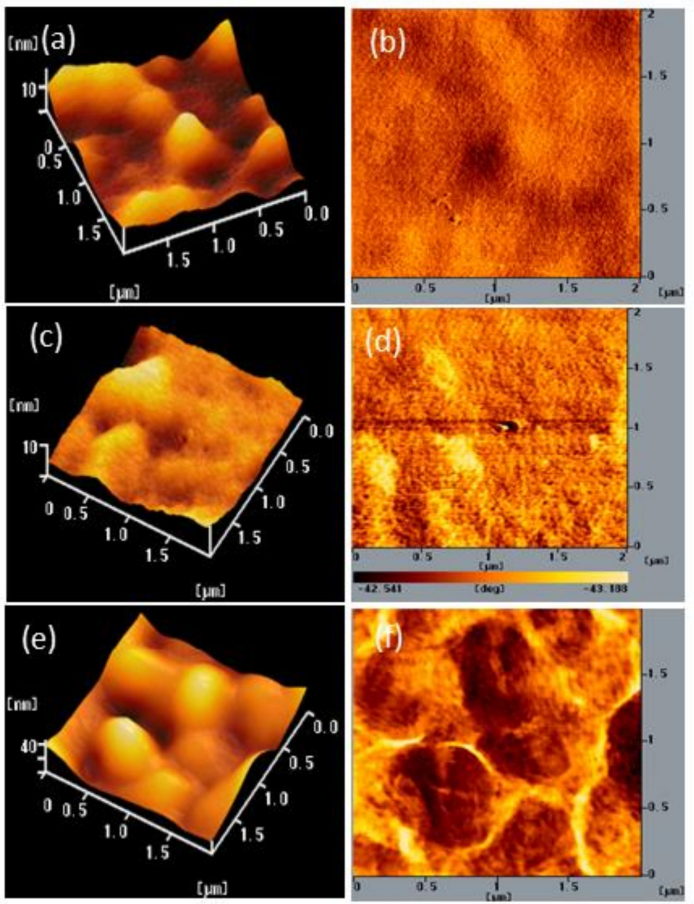

Figure 7. (a,c,e) Topographic and (b,d,f) phase AFM images of a BCP film after storage at $30{ }^{\circ} \mathrm{C}$ and $35 \%$ relative humidity for $(\mathbf{a}, \mathbf{b}) 0,(\mathbf{c}, \mathbf{d}) 5$, and $(\mathbf{e}, \mathbf{f}) 10$ days.
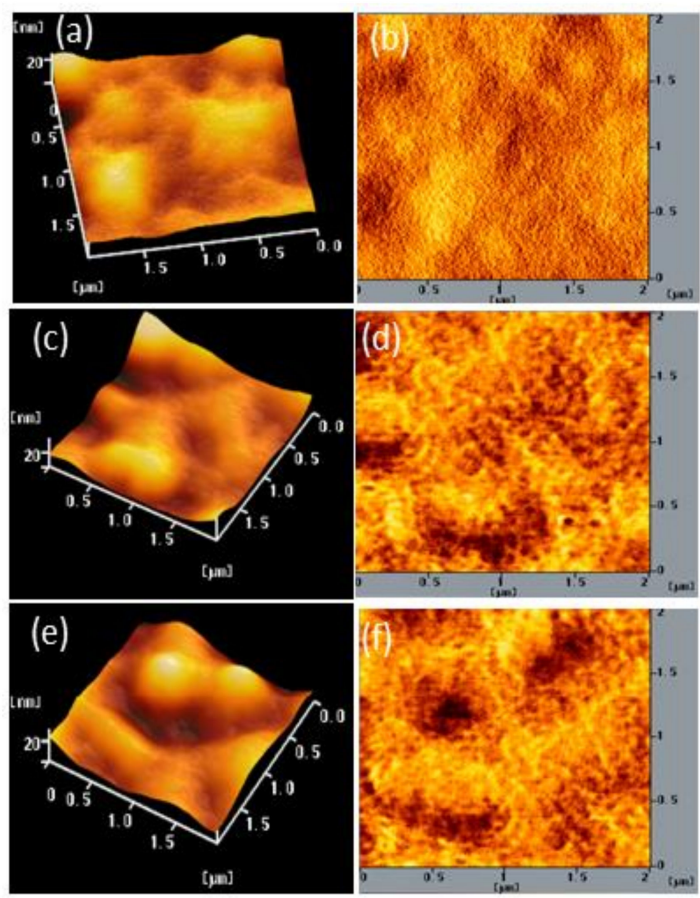

Figure 8. (a,c,e) Topographic and (b,d,f) phase AFM images of a BCP/PMMA (5:1, w/w) film after storage at $30{ }^{\circ} \mathrm{C}$ and $35 \%$ relative humidity for $(\mathbf{a}, \mathbf{b}) 0,(\mathbf{c}, \mathbf{d}) 5$, and (e,f) 10 days. 

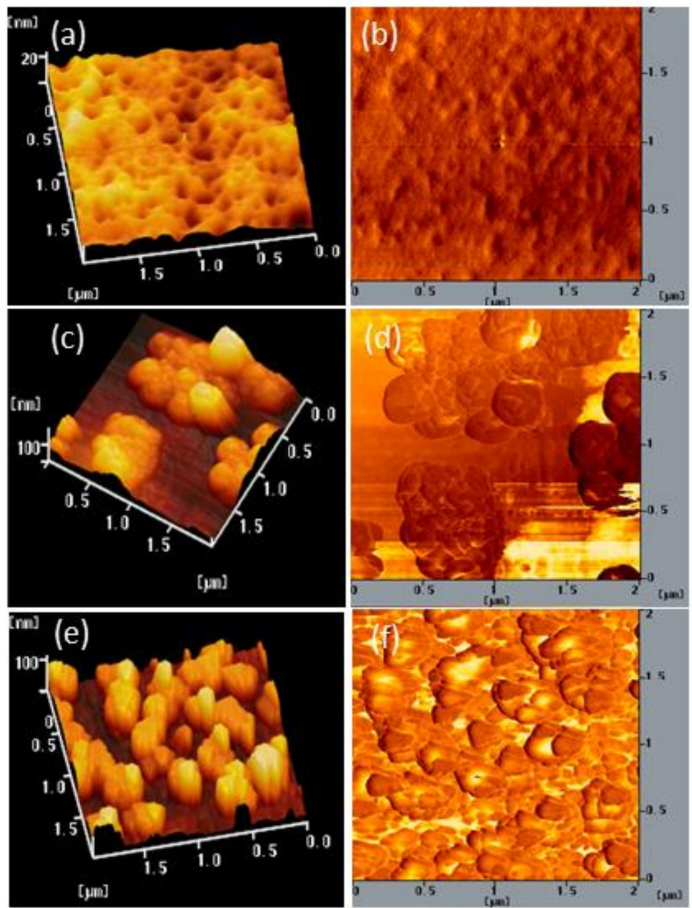

Figure 9. (a,c,e) Topographic and (b,d,f) phase AFM images of a BCP/PVP $(5: 1, w / w)$ film after storage at $30{ }^{\circ} \mathrm{C}$ and $35 \%$ relative humidity for $(\mathbf{a}, \mathbf{b}) 0,(\mathbf{c}, \mathbf{d}) 5$, and (e,f) 10 days.

To examine the mechanism behind the morphological changes of the composite films under ambient conditions, we measured the hydrophobicity/hydrophilicity of the $\mathrm{BCP} / \mathrm{PMMA}$ and $\mathrm{BCP} / \mathrm{PVP}$ films using a $\mathrm{CA}$ meter. Figures $\mathrm{S} 4$ and $\mathrm{S} 5$ display photographs of water droplets on the BCP, BCP/PMMA, and BCP/PVP films that had been stored at $30{ }^{\circ} \mathrm{C}$ and $35 \%$ relative humidity for 0,5 , and 10 days. Table S2 lists the CAs of the $\mathrm{BCP}$, $\mathrm{BCP} / \mathrm{PMMA}$, and $\mathrm{BCP} / \mathrm{PVP}$ films. Initially, the $\mathrm{CA}$ of the $\mathrm{BCP}$ film was $74.5^{\circ}$, suggesting low hydrophobicity; the $\mathrm{CA}$ decreased upon increasing the storage time, consistent with an increase in the permeation of moisture into this film and the significant change in the morphology of BCP film observed in Figure 7. The CA of the BCP film increased upon increasing the content of PMMA. Moreover, the CA of the BCP/PMMA $(5: 1, w / w)$ film did not decrease with increasing the storage time. The presence of the highly hydrophobic PMMA prevented the intrusion of moisture into the $\mathrm{BCP}$ film, consistent with the high morphological stability observed for the BCP/PMMA composite film in Figure 8. In contrast, the CA decreased upon increasing the PVP content in the BCP/PVP composite films. Furthermore, the CA of the BCP/PVP $(5: 1, w / w)$ film decreased significantly upon increasing the storage time. The presence of PVP, with low hydrophobicity, enhanced the permeation of moisture into the $\mathrm{BCP}$ film. As a result, phase separation of $\mathrm{BCP}$ and $\mathrm{PVP}$ occurred, promoting the formation of $\mathrm{BCP}$-based crystals in the $\mathrm{BCP} / \mathrm{PVP}$ film, as observed in Figure 9.

\section{PV Characteristics}

Figure 10 presents the best PV performance of PVSCs featuring the $\mathrm{BCP}, \mathrm{BCP} / \mathrm{PMMA}$, and BCP/PVP films as hole-blocking/electron-transporting interfacial layers; the statistical values of $V_{\mathrm{OC}}, J_{\mathrm{SC}}, \mathrm{FF}$, and PCE are summarized in Table 1 . Four runs of PV evaluation tests were performed for each PVSC sample. For PVSC I, prepared with BCP as the electron-transporting interfacial layer, a value of $V_{\mathrm{OC}}$ of $0.90 \mathrm{~V}$, a value of $J_{\mathrm{SC}}$ of $21.2 \mathrm{~mA}$ $\mathrm{cm}^{-2}$, an FF of 0.62 , and a PCE of $11.78 \%$ were obtained. Compared with the BCP-based PVSC, the values of $V_{\mathrm{OC}}$ and the FFs of the PVSCs incorporating the BCP/PMMA blend films (PVSCs II-IV) did not change significantly upon varying the PMMA content; the values of $J_{\mathrm{SC}}$ and the PCEs did, however, decrease slightly upon increasing the PMMA 
content, consistent with the lower BCP content in the electron-transporting interfacial layer. Decreasing the $\mathrm{BCP}$ content inhibited electron transport from the $\mathrm{MAPbI}_{3}$ layer to the cathode. The lowest values of $J_{\mathrm{SC}}$ and PCE were those of PVSC IV incorporating $40 \mathrm{wt} . \%$ PMMA. In contrast, the values of $V_{\mathrm{OC}}, J_{\mathrm{SC}}$, and PCE of the PVSCs incorporating BCP/PVP blend films (PVSCs V-VII) increased upon increasing the PVP content, and were greater than those of the BCP-based PVSC. The highest values of $V_{\mathrm{OC}}(0.92 \mathrm{~V}), J_{\mathrm{SC}}(21.72 \mathrm{~mA}$ $\left.\mathrm{cm}^{-2}\right)$, FF (0.62), and PCE (12.41\%) were obtained for PVSC VI, prepared with BCP / PVP $(5: 1, w / w)$ as the hole-blocking/electron-transporting interfacial layer. The presence of PVP at the interface between $\mathrm{PC}_{61} \mathrm{BM}$ and the cathode might have induced the formation of a dipole layer, thereby enhancing the built-in potential across the cell and facilitating electron transport from the perovskite layer to the cathode [45]. As a result, the PV properties of the BCP/PVP-based PVSCs were enhanced. Nevertheless, a larger PVP content in the $\mathrm{BCP} / \mathrm{PVP}$ blend film did not improve the PV properties of PVSC VII, which provided a PCE lower than that of PVSC I. The poor compatibility of BCP and PVP would inhibit electron transport from $\mathrm{PC}_{61} \mathrm{BM}$ to the cathode. Consequently, the $\mathrm{PV}$ performance of the $\operatorname{BCP} / \operatorname{PVP}(5: 2, w / w)$-based PVSC VII was poor. Table S3 reveals that the PV properties of our PVSCs reported herein are comparable with those of similarly structured PVSCs reported previously in the literature.
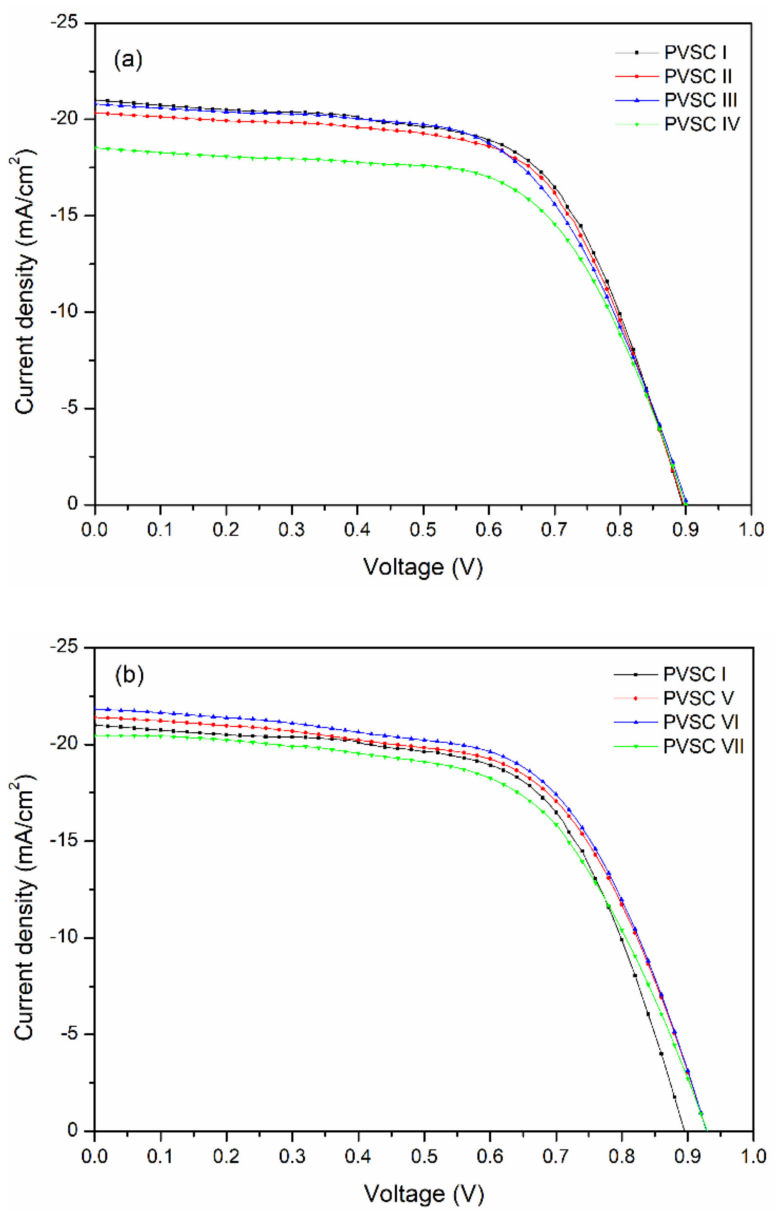

Figure 10. Current density-potential plots of PVSCs incorporating BCP, BCP/PMMA, and BCP/PVP films ((a) BCP (PVSC I), BCP/PMMA (PVSC II-IV); (b) BCP/PVP (PVSC V-VII)), illuminated under AM 1.5G light at $100 \mathrm{~mW} \mathrm{~cm} \mathrm{~cm}^{-2}$. 
Table 1. PV properties of PVSCs incorporating BCP, BCP/PMMA, and BCP/PVP films.

\begin{tabular}{|c|c|c|c|c|c|c|c|c|}
\hline PVSC & $\begin{array}{c}\text { Interfacial } \\
\text { Layer }\end{array}$ & $\begin{array}{l}\text { Composition } \\
(w / w)\end{array}$ & $V_{\text {OC }}(\mathrm{V})$ & $\begin{array}{c}J_{\mathrm{SC}}(\mathrm{mA} \\
\left.\mathrm{cm}^{-2}\right)\end{array}$ & FF & $\begin{array}{l}\text { PCE } \\
(\%)\end{array}$ & $\begin{array}{c}\text { Best PCE } \\
(\%)\end{array}$ & $\begin{array}{c}\mathrm{JSC}_{\mathrm{SC}}{ }^{*} \\
\left(\mathrm{~mA} \mathrm{~cm}{ }^{-2}\right)\end{array}$ \\
\hline PVSC-I & $\mathrm{BCP}$ & 0.0 & $0.89 \pm 0.01$ & $21.18 \pm 0.02$ & $0.61 \pm 0.01$ & $11.50 \pm 0.28$ & 11.78 & 18.56 \\
\hline PVSC-II & BCP / PMMA & $10: 1$ & $0.89 \pm 0.01$ & $20.69 \pm 0.01$ & $0.61 \pm 0.01$ & $11.23 \pm 0.38$ & 11.61 & 18.08 \\
\hline PVSC-III & BCP/PMMA & $5: 1$ & $0.89 \pm 0.01$ & $20.92 \pm 0.02$ & $0.60 \pm 0.01$ & $11.17 \pm 0.39$ & 11.56 & 18.07 \\
\hline PVSC-IV & BCP/PMMA & $5: 2$ & $0.89 \pm 0.01$ & $18.49 \pm 0.01$ & $0.63 \pm 0.01$ & $10.37 \pm 0.29$ & 10.66 & 17.56 \\
\hline PVSC-V & BCP /PVP & $10: 1$ & $0.91 \pm 0.01$ & $21.33 \pm 0.02$ & $0.61 \pm 0.01$ & $11.84 \pm 0.23$ & 12.07 & 18.82 \\
\hline PVSC-VI & $\mathrm{BCP} / \mathrm{PVP}$ & $5: 1$ & $0.91 \pm 0.01$ & $21.71 \pm 0.01$ & $0.60 \pm 0.02$ & $11.85 \pm 0.56$ & 12.41 & 19.14 \\
\hline PVSC-VII & $\mathrm{BCP} / \mathrm{PVP}$ & $5: 2$ & $0.91 \pm 0.02$ & $20.45 \pm 0.01$ & $0.61 \pm 0.01$ & $11.35 \pm 0.35$ & 11.70 & 18.27 \\
\hline
\end{tabular}

${ }^{*}$ JSC values of the PVSCs calculated from EQE spectra.

Figure 11 displays the external quantum efficiency (EQE) spectra of the PVSCs incorporating films of $\mathrm{BCP}, \mathrm{BCP} / \mathrm{PMMA}$, and $\mathrm{BCP} / \mathrm{PVP}$. Similar EQE profiles of $\mathrm{MAPbI}_{3}$-based PVSCs have been reported several times previously $[11,47,48]$. The partial photo-response near $400 \mathrm{~nm}$ arose from the absorption of $\mathrm{PC}_{61} \mathrm{BM}$ [49]. Relative to the BCP-based PVSC $\mathrm{I}$, the EQEs decreased upon increasing the amount of PMMA in the BCP/PMMA-based PVSC-II, PVSC-III, and PVSC-IV. A greater PMMA content in the BCP/PMMA blend film inhibited the transport of electrons from the $\mathrm{MAPbI}_{3}$ layer to the cathode. As a result, the EQEs decreased when the PVSCs had higher PMMA contents. In contrast, the EQEs of the BCP/PVP-based PVSC V, PVSC-VI, and PVSC-VII were greater than those of the $\mathrm{BCP}$-based PVSC I. The presence of PVP at the interface between the $\mathrm{PC}_{61} \mathrm{BM}$ layer and the cathode might have promoted the transport of electrons from the $\mathrm{PC}_{61} \mathrm{BM}$ layer to the cathode. Nevertheless, a larger PVP content in the BCP/PVP blend film did not enhance the EQE of PVSC VII-it was lower than that of PVSC I. Moreover, the JSC values of the PVSCs calculated from EQE spectra are summarized in Table 1. The $J_{S C}$ values are in relatively good agreement with the values measured under irradiation of AM $1.5 \mathrm{G}$ light at $100 \mathrm{~mW} \mathrm{~cm}^{-2}$.
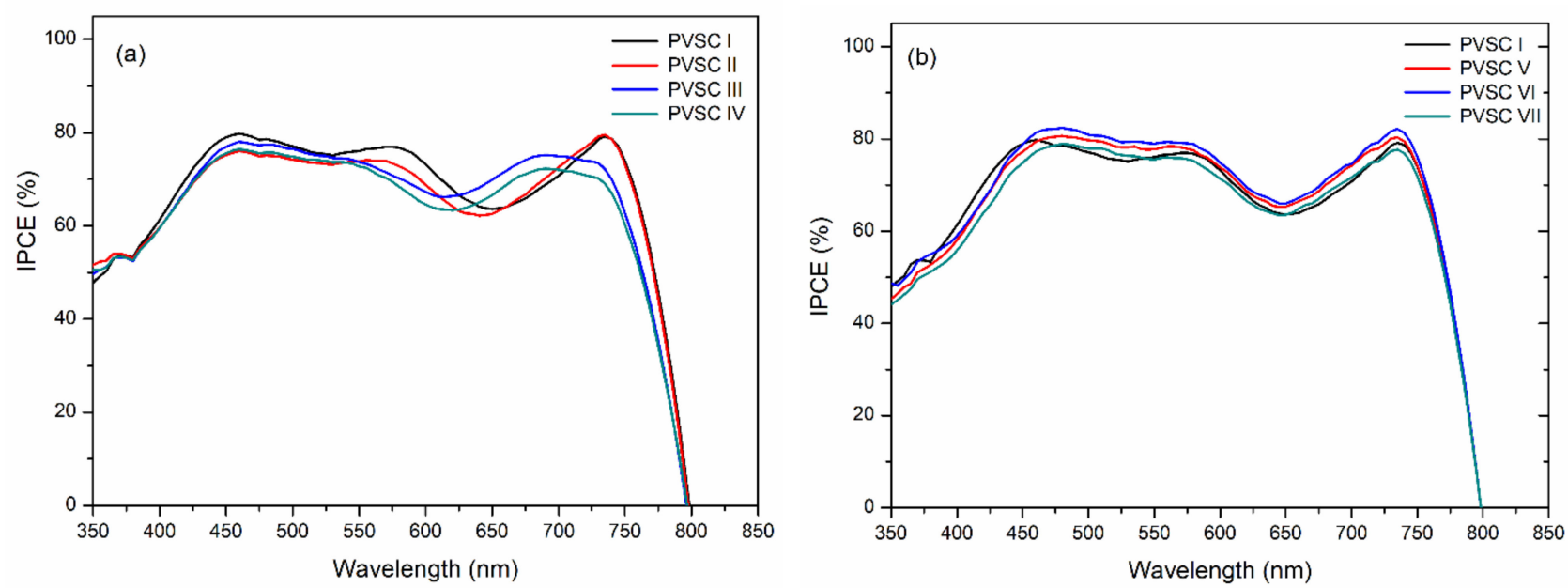

Figure 11. EQE (external quantum efficiency) spectra of PVSCs incorporating films of BCP, BCP/PMMA, and BCP/PVP films ((a) BCP (PVSC I), BCP/PMMA (PVSC II-IV); (b) BCP/PVP (PVSC V-VII)), recorded under monochromatic irradiation.

The storage stability of the BCP-, BCP/PMMA-, and BCP/PVP-based PVSCs measured at $30{ }^{\circ} \mathrm{C}$ and $35 \%$ relative humidity is displayed in Figure 12. The PCE-stabilities of the BCP/PMMA-based PVSC II and PVSC III were superior to that of the BCP-based PVSC-I. Higher PCE-stabilities were observed for the BCP/PMMA-based PVSCs upon increasing their PMMA content, consistent with the higher hydrophobicity of PMMA preventing moisture from entering the BCP film. Nevertheless, the PCE-stability of PVSC IV was lower than those of PVSC II and PVSC III, presumably because of the poorer PV 
properties of PVSC IV with its higher PMMA content. In contrast, the PCE-stabilities of the BCP / PVP-based PVSCs were poorer than that of the BCP-based PVSC-I, with lower PCE-stability observed upon increasing the PVP content. The phase separation of BCP and PVP, and the high hydrophilicity of PVP, promoted the intrusion of moisture into the $\mathrm{BCP}$ film. Consequently, the PVSCs incorporating the BCP/PVP composite film exhibited poor PCE-stability.
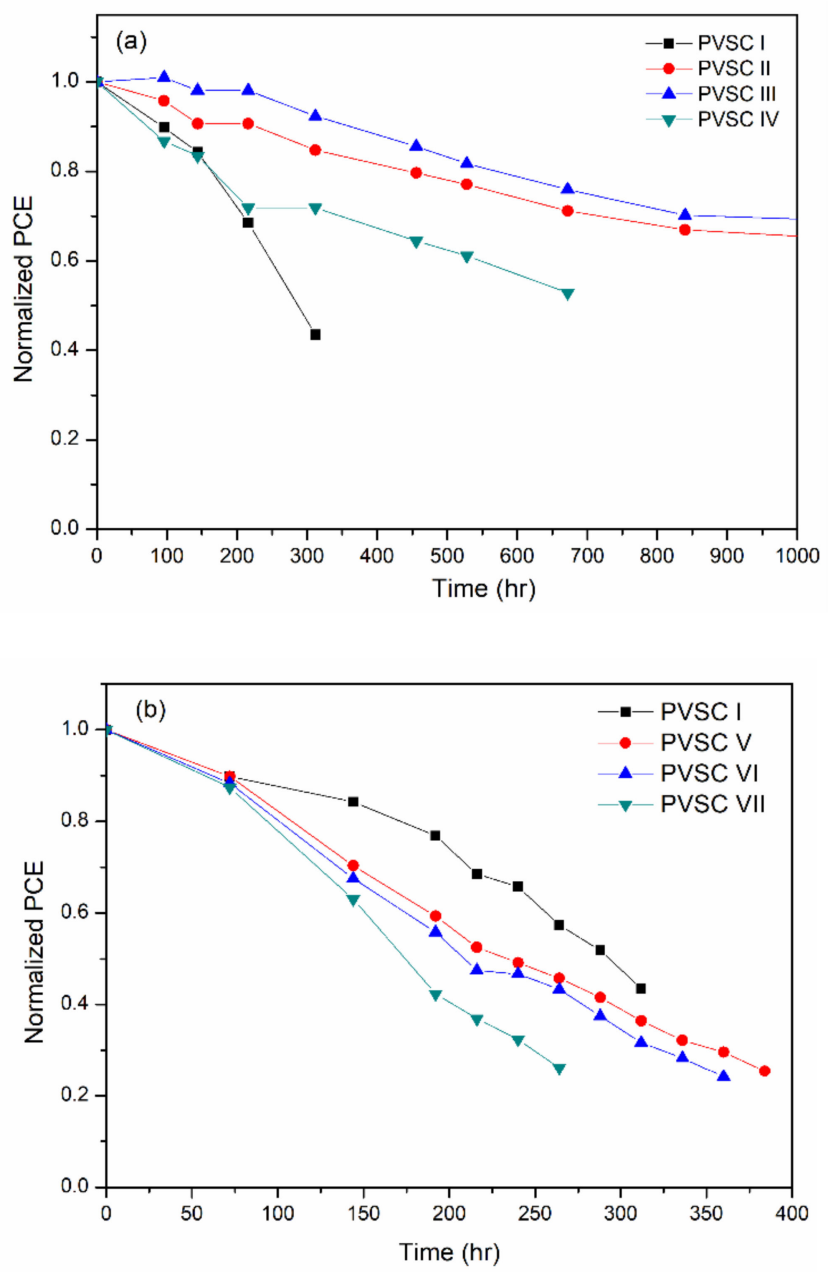

Figure 12. Storage-stability of PVSCs incorporating BCP, BCP/PMMA, and BCP/PVP films ((a) BCP (PVSC I), BCP/PMMA (PVSC II-IV); (b) BCP/PVP (PVSC V-VII); measured at $30{ }^{\circ} \mathrm{C}$ and $35 \%$ relative humidity).

In addition, the time dependence of the $V_{\mathrm{OC}}$ and $J_{\mathrm{SC}}$ of the PVSC I, PVSC III, and PVSC VI (measured at $30{ }^{\circ} \mathrm{C}$ and $35 \%$ relative humidity) is shown in Figure S6. The results indicated that the $V_{\mathrm{OC}}$ values of the PVSCs slightly decreased with increasing storage time, whereas the $J_{\mathrm{SC}}$ values of the PVSCs decreased considerably with increasing storage time. The intrusion of moisture into the $\mathrm{MAPbI}_{3}$ layer enhanced the impendence of the cells. As a result, the $J_{\mathrm{SC}}$ values of the PVSCs decreased. The $J_{\mathrm{SC}}$ dominated the PCE degradation of PVSCs.

To study the influence of moisture permeation on the stability of the PVSC device, the storage stability of the BCP-, BCP/PMMA-, and BCP/PVP-based PVSCs was measured at $30{ }^{\circ} \mathrm{C}$ and $60 \%$ relative humidity; details concerning these measurements are displayed in Figure S7. The stability of the PVSCs at $60 \%$ relative humidity was substantially reduced compared with that of the PVSCs at 35\% relative humidity, suggesting that the intrusion rate of moisture into the $\mathrm{MAPbI}_{3}$ layer is enhanced by increasing the relative humidity. 
Therefore, the degradation rate of the $\mathrm{MAPbI}_{3}$-based PVSCs increased as the cells were stored under higher relative humidity.

\section{Conclusions}

The PV properties and stabilities of $\mathrm{MAPbI}_{3}$-based PVSCs incorporating $\mathrm{BCP} / \mathrm{PMMA}$ and BCP/PVP films as hole-blocking/electron-transporting interfacial layers have been studied. The storage-stability of the BCP/PMMA-based PVSCs was enhanced significantly relative to that of the BCP-based PVSC, but the PV performance decreased slightly after the incorporation of PMMA. The improved storage-stability arose from the greater hydrophobicity and moisture-resistance of the resulting $\mathrm{BCP} / \mathrm{PMMA}$ layer. A higher content of PMMA in the $\mathrm{BCP}$ layer inhibited charge transfer from the $\mathrm{MAPbI}_{3}$ layer to the cathode, resulting in a lower short-circuit current density and a less efficient PVSC. In contrast, the $\mathrm{PV}$ performance of BCP/PVP-based PVSCs was enhanced relative to that of the BCP-based PVSC, but their storage-stability was poor. The presence of PVP promoted the electrontransporting across the BCP-based interfacial layer to cathode and resulted in PVSCs having higher current densities and PCEs. Nevertheless, poor compatibility between PVP and BCP resulted in the BCP/PVP-based PVSCs displaying poor storage-stability.

Supplementary Materials: The following are available online at https://www.mdpi.com/2073-436 0/13/1/42/s1, Figure S1: (a) UV-Vis absorption and (b) PL spectra of the $\mathrm{MAPbI}_{3}$ perovskite film., Figure S2: (a, c, e, g) Topographic and (b, d, f, h) phase AFM images of (a, b) BCP, (c, d) BCP/PMMA $(10: 1, w / w),(\mathrm{e}, \mathrm{f}) \mathrm{BCP} / \mathrm{PMMA}(5: 1, w / w)$, and $(\mathrm{g}, \mathrm{h}) \mathrm{BCP} / \mathrm{PMMA}(5: 2, w / w)$ hole-blocking/electrontransporting interfacial layers, recorded after thermal treatment $\left(80^{\circ} \mathrm{C}, 5 \mathrm{~min}\right)$., Figure S3: (a, c, e, g) Topographic and (b, d, f, h) phase AFM images of (a, b) BCP, (c, d) BCP/PVP $(10: 1, w / w),(\mathrm{e}, \mathrm{f})$ $\mathrm{BCP} / \mathrm{PVP}(5: 1, w / w)$, and $(\mathrm{g}, \mathrm{h}) \mathrm{BCP} / \mathrm{PVP}(5: 2, w / w)$ hole-blocking/electron-transporting interfacial layers, recorded after thermal treatment $\left(80^{\circ} \mathrm{C}, 5 \mathrm{~min}\right)$., Figure S4: Photographs of water droplets on (a) BCP, (b) $\mathrm{PC}_{61} \mathrm{BM},(\mathrm{c}, \mathrm{d}, \mathrm{e}) \mathrm{BCP} / \mathrm{PMMA}$ (10:1, 5:1, and 5:2, w/w), and (f, g, h) BCP/PVP (10:1, 5:1, and 5:2, w/w) films., Figure S5: Photographs of water droplets on (a-c) BCP, (d-f) BCP/PMMA (5:1, $w / w)$, and (g-i) $\mathrm{BCP} / \mathrm{PVP}(5: 1, w / w)$ films after storage at $30{ }^{\circ} \mathrm{C}$ and $35 \%$ relative humidity for 0 , 5, and 10 days., Figure S6: Time dependence of $V_{\mathrm{OC}}$ and $J_{\mathrm{SC}}$ of the PVSC I, PVSC III, and PVSC VI (measured at $30{ }^{\circ} \mathrm{C}$ and $35 \%$ relative humidity)., Figure S7: Storage-stability of PVSCs incorporating $\mathrm{BCP}, \mathrm{BCP} / \mathrm{PMMA}$, and $\mathrm{BCP} / \mathrm{PVP}$ (measured at $30^{\circ} \mathrm{C}$ and $60 \%$ relative humidity)., Table S1: Crystal sizes of $\mathrm{MAPbI}_{3}$ film coated with $\mathrm{BCP}, \mathrm{BCP} / \mathrm{PMMA}$, and BCP/PVP layers after storage at $30^{\circ} \mathrm{C}$ and $35 \%$ relative humidity for 0,5 , and 10 days., Table S2: Surface roughnesses and CAs of films of BCP, $\mathrm{BCP} / \mathrm{PMMA}$, and $\mathrm{BCP} / \mathrm{PVP}$ layers after storage at $30^{\circ} \mathrm{C}$ and $35 \%$ relative humidity for 0,5 , and 10 days., Table S3: PV performances of previously reported PVSCs, compared with those measured in this present study.

Author Contributions: Conceptualization R.-H.L.; Methodology, G.-Z.L.; Validation, C.-S.D.; Investigation, J.-Y.W., B.-T.L., T.-M.W.; Resources, R.-H.L.; Writing-Original Draft Preparation, R.-H.L.; Writing-Review \& Editing, C.-F.H., R.-H.L.; Supervision, R.-H.L.; Project Administration, R.-H.L.; Funding Acquisition, R.-H.L. All authors have read and agreed to the published version of the manuscript.

Funding: This research was funded by [the Ministry of Science and Technology of Taiwan] grant number [MOST 109-2221-E-005-070] and the APC was funded by [National Chung Hsing University].

Acknowledgments: We thank the Ministry of Science and Technology of Taiwan for financial support.

Conflicts of Interest: The authors declare no conflict of interest.

\section{References}

1. Kim, J.Y.; Lee, J.W.; Jung, H.S.; Shin, H.; Park, N.G. High-efficiency perovskite solar cells. Chem. Rev. 2020, 120, 7867-7918. [CrossRef]

2. Xing, G.; Mathews, N.; Sun, S.; Lim, S.S.; Lim, Y.M.; Gratzel, M.; Mhaisalkar, S.; Sum, T.C. Long-range balanced electron- and hole-transport lengths in organic-inorganic $\mathrm{CH}_{3} \mathrm{NH}_{3} \mathrm{PbI}_{3}$. Science 2013, 342, 344-347. [CrossRef]

3. Li, S.; Ren, H.; Yan, Y. Boosting efficiency of planar heterojunction perovskite solar cells to $21.22 \%$ by a facial two step deposition strategy. Appl. Surf. Sci. 2019, 484, 1191-1197. [CrossRef] 
4. Stranks, S.D.; Eperon, G.E.; Grancini, G.; Menelaou, C.; Alcocer, M.J.P.; Leijtens, T.; Herz, L.M.; Petrozza, A.; Snaith, H.J. Electronhole diffusion lengths exceeding 1 micrometer in an organometal trihalide perovskite absorber. Science 2013, 342, 341-344. [CrossRef] [PubMed]

5. Dong, Q.; Fang, Y.; Shao, Y.; Mulligan, P.; Qiu, J.; Cao, L.; Huang, J. Electron-hole diffusion lengths $>175 \mathrm{~m}$ in solution grown $\mathrm{CH}_{3} \mathrm{NH}_{3} \mathrm{PbI}_{3}$ single crystals. Science 2015, 347, 967-970. [CrossRef] [PubMed]

6. Kojima, A.; Teshima, K.; Shirai, Y.; Miyasaka, T. Organometal halide perovskites as visible-light sensitizers for photovoltaic cells. J. Am. Chem. Soc. 2009, 131, 6050-6051. [CrossRef]

7. Docampo, P.; Ball, J.M.; Darwich, M.; Eperon, G.E.; Snaith, H.J. Efficient organometal trihalide perovskite planar-heterojunction solar cells on flexible polymer substrates. Nat. Commun. 2013, 4, 2761. [CrossRef]

8. Song, Z.; Watthage, S.C.; Phillips, A.B.; Heben, M.J. Pathways toward high-performance perovskite solar cells: Review of recent advances in organo-metal halide perovskites for photovoltaic applications. J. Photon. Energy 2016, 6, 022001. [CrossRef]

9. Gao, B.; Meng, J. RbCs(MAFA) $\mathrm{PbI}_{3}$ perovskite solar cell with $22.81 \%$ efficiency using the precise ions cascade regulation. Appl. Surf. Sci. 2020, 530, 147240. [CrossRef]

10. Saliba, M.; Matsui, T.; Seo, J.; Domanski, K.; Baena, J.P.C.; Nazeeruddin, M.K.; Zakeeruddin, S.M.; Tress, W.; Abate, A.; Hagfeldtd, A.; et al. Cesium-containing triple cation perovskite solar cells: Improved stability, reproducibility and high efficiency. Energy Environ. Sci. 2016, 9, 1989. [CrossRef]

11. Chen, W.; Xu, L.; Feng, X.; Jie, J.; He, Z. Metal acetylacetonate series in interface engineering for full low-temperature-processed, high-performance, and stable planar perovskite solar cells with conversion efficiency over $16 \%$ on $1 \mathrm{~cm}^{2}$ scale. Adv. Mater. 2017, 29, 1603923. [CrossRef] [PubMed]

12. Ghoreishi, F.S.; Ahmadi, V.; Poursalehi, R.; Pour, M.S.; Johansson, M.B.; Boschloo, G.; Johansson, E.M.J. Enhanced performance of $\mathrm{CH}_{3} \mathrm{NH}_{3} \mathrm{PbI}_{3}$ perovskite solar cells via interface modification using phenyl ammonium iodide derivatives. J. Power Sources 2020, 473, 228492. [CrossRef]

13. Li, D.; Chao, L.; Chen, C.; Ran, X.; Wang, Y.; Niu, T.; Lv, S.; Wu, H.; Xia, Y.; Ran, C.; et al. In situ interface engineering for highly efficient electron-transport layer-free perovskite solar cells. Nano Lett. 2020, 20, 5799-5806. [CrossRef] [PubMed]

14. Girolamo, D.D.; Giacomo, F.D.; Matteocci, F.; Marrani, A.G.; Dini, D.; Abate, A. Progress, highlights and perspectives on NiO in perovskite photovoltaics. Chem. Sci. 2020, 11, 7746-7759. [CrossRef]

15. Kong, J.; Wang, H.; Röhr, J.A.; Fishman, Z.S.; Zhou, Y.; Li, M.; Cotlet, M.; Kim, G.; Karpovich, C.; Antonio, F.; et al. Perovskite solar cells with enhanced fill factors using polymer capped solvent annealing. ACS Appl. Energy Mater. 2020, 3, 7231-7238. [CrossRef]

16. Kuo, D.W.; Liu, G.Z.; Lee, R.H. Star-shaped molecule with planar triazine core and perylene diimide branches as an n-type additive for bulk-heterojunction perovskite solar cells. Dye. Pigment. 2019, 170, 107562. [CrossRef]

17. Chu, H.Y.; Hong, J.Y.; Huang, C.F.; Wu, J.Y.; Wang, T.L.; Wu, T.M.; Lee, R.H. Enhanced photovoltaic properties of perovskite solar cells by the addition of cellulose derivatives to $\mathrm{MAPbI}_{3}$ based photoactive layer. Cellulose 2019, 26, 9229-9239. [CrossRef]

18. Guo, Y.L.; Shoyama, K.; Sato, W.; Nakamura, E. Polymer stabilization of lead(II) perovskite cubic nanocrystals for semitransparent solar cells. Adv. Energy Mater. 2016, 6, 1502317. [CrossRef]

19. Liu, C.; Huang, Z.; Hu, X.; Meng, X.; Huang, L.; Xiong, J.; Tan, L.; Chen, Y. Grain boundary modification via F4-TCNQ to reduce defects of perovskite solar cells with excellent device performance. ACS Appl. Mater. Interfaces 2018, 10, 1909-1916. [CrossRef]

20. Huang, Z.Q.; Hu, X.T.; Liu, C.; Tan, L.C.; Chen, Y.W. Nucleation and crystallization control via polyurethane to enhance the bendability of perovskite solar cells with excellent device performance. Adv. Funct. Mater. 2017, 27, 1703061. [CrossRef]

21. Yang, Y.; Song, J.; Zhao, Y.L.; Zhu, L.; Gu, X.Q.; Gu, Y.Q.; Che, M.; Qiang, Y.H. Ammonium-iodide-salt additives induced photovoltaic performance enhancement in one-step solution process for perovskite solar cells. J. Alloy. Compd. 2016, 684, 84-90. [CrossRef]

22. Zhu, T.; Liu, D.; Zheng, J.; Coolen, L.; Pauporte, T. PEAI-based interfacial layer for high-efficiency and stable solar cells based on a MACl-mediated grown $\mathrm{FA}_{0.94} \mathrm{MA}_{0.06} \mathrm{PbI}_{3}$ perovskite. ACS Appl. Mater. Interfaces 2020, 12, 37197-37207. [CrossRef]

23. Saliba, M.; Matsui, T.; Domanski, K.; Seo, J.Y.; Ummadisingu, A.; Zakeeruddin, S.M.; Baena, J.P.C.; Tress, W.R.; Abate, A.; Hagfeldt, A.; et al. Incorporation of rubidium cations into perovskite solar cells improves photovoltaic performance. Science 2016, 354, 206-209. [CrossRef]

24. Chai, L.; Zhong, M.; Li, X.; Wu, N.; Zhou, J. The effect of bromine doping on the perovskite solar cells modified by PVP/PEG polymer blends. Superlattices Microstruct. 2018, 120, 279-287. [CrossRef]

25. Chang, C.Y.; Chu, C.Y.; Huang, Y.C.; Huang, C.W.; Chang, S.Y.; Chen, C.A.; Chao, C.Y.; Su, W.F. Tuning perovskite morphology by polymer additive for high efficiency solar cell. ACS Appl. Mater. Interfaces 2015, 7, 4955-4961. [CrossRef] [PubMed]

26. Li, F.; Liu, M. Recent efficient strategies for improving the moisture stability of perovskite solar cells. J. Mater. Chem. A 2017, 5, 15447-15459. [CrossRef]

27. Chen, W.; Wu, Y.Z.; Yue, Y.F.; Liu, J.; Zhang, W.J.; Yang, X.D.; Chen, H.; Bi, E.B.; Ashraful, I.; Gratzel, M.; et al. Efficient and stable large-area perovskite solar cells with inorganic charge extraction layers. Science 2015, 350, 944-948. [CrossRef]

28. Zhu, Z.; Bai, Y.; Liu, X.; Chueh, C.-C.; Yang, S.; Jen, A.K.Y. Perovskite Solar Cells Using Highly crystalline $\mathrm{SnO}_{2}$ nanocrystals as the robust electron-transporting layer. Adv. Mater. 2016, 28, 6478-6484. [CrossRef]

29. Hwang, I.; Jeong, I.; Lee, J.; Ko, M.J.; Yong, K. Enhancing stability of perovskite solar cells to moisture by the facile hydrophobic passivation. ACS Appl. Mater. Interfaces 2015, 7, 17330-17336. [CrossRef] 
30. Babu, V.; Pineda, R.F.; Ahmad, T.; Alvarez, A.O.; Castriotta, L.A.; Carlo, A.D.; Santiago, F.F.; Wojciechowski, K. Improved stability of inverted and flexible perovskite solar cells with carbon electrode. ACS Appl. Energy Mater. 2020, 3, 5126-5134. [CrossRef]

31. Kundu, S.; Kelly, T.L. Improving the moisture stability of perovskite solar cells by using PMMA/P3HT based hole-transport layers. Mater. Chem. Front. 2018, 2, 81-89. [CrossRef]

32. Habisreutinger, S.N.; Leijtens, T.; Eperon, G.E.; Stranks, S.D.; Nicholas, R.J.; Snaith, H.J. Carbon nanotube/polymer composites as a highly stable hole collection layer in perovskite solar cells. Nano Lett. 2014, 14, 5561-5568. [CrossRef] [PubMed]

33. Wu, C.; Li, H.; Yan, Y.; Chi, B.; Felice, K.M.; Moore, R.B.; Magill, B.A.; Mudiyanselage, R.R.H.H.; Khodaparast, G.A.; Sanghadasa, M.; et al. Highly-stable organo-lead halide perovskites synthesized through green self-assembly process. Sol. RRL 2018, 2, 1800052. [CrossRef]

34. Zhou, P.; Fang, Z.; Zhou, W.; Qiao, Q.; Wang, M.; Chen, T.; Yang, S. Nonconjugated polymer poly(vinylpyrrolidone) as an efficient interlayer promoting electron transport for perovskite solar cells. ACS Appl. Mater. Interfaces 2017, 9, 32957-32964. [CrossRef]

35. Li, B.; Zhang, Y.; Fu, L.; Yu, T.; Zhou, S.; Zhang, L.; Yin, L. Surface passivation engineering strategy to fully-inorganic cubic $\mathrm{CsPbI}_{3}$ perovskites for high-performance solar cells. Nat. Commun. 2018, 9, 1076. [CrossRef]

36. Zhang, Y.; Zhuang, X.; Zhou, K.; Cai, C.; Hu, Z.; Zhang, J.; Zhu, Y. Amorphous polymer with C=O to improve the performance of perovskite solar cells. J. Mater. Chem. C 2017, 5, 9037-9043. [CrossRef]

37. Ding, Y.; Yao, X.; Zhang, X.; Wei, C.; Zhao, Y. Surfactant enhanced surface coverage of $\mathrm{CH}_{3} \mathrm{NH}_{3} \mathrm{PbI}_{3-\mathrm{x}} \mathrm{Cl}_{\mathrm{x}}$ perovskite for highly efficient mesoscopic solar cells. J. Power Sources 2014, 272, 351-355. [CrossRef]

38. Manshor, N.A.; Wali, Q.; Wong, K.K.; Muzakir, S.K.; Fakharuddin, A.; Mende, L.S.; Jose, R. Humidity versus photo-stability of metal halide perovskite films in a polymer matrix. Phys. Chem. Chem. Phys. 2016, 18, 21629-21639. [CrossRef]

39. Xiong, H.; DeLuca, G.; Rui, Y.; Zhang, B.; Li, Y.; Zhang, Q.; Wang, H.; Reichmanis, E. Modifying perovskite films with polyvinylpyrrolidone for ambient-air-stable highly bendable solar cells. ACS Appl. Mater. Interfaces 2018, 10, 35385-35394. [CrossRef]

40. Chen, C.; Zhang, S.; Wu, S.; Zhang, W.; Zhu, H.; Xiong, Z.; Zhang, Y.; Chen, W. Effect of BCP buffer layer on eliminating charge accumulation for high performance of inverted perovskite solar cells. RSC Adv. 2017, 7, 35819-35826. [CrossRef]

41. Butscher, J.F.; Intorp, S.; Kress, J.; An, Q.; Hofstetter, Y.J.; Hippchen, N.; Paulus, F.; Bunz, U.H.F.; Tessler, N.; Vaynzof, Y. Enhancing the open-circuit voltage of perovskite solar cells by embedding molecular dipoles within their hole-blocking layer. ACS Appl. Mater. Interfaces 2020, 12, 3572-3579. [CrossRef] [PubMed]

42. Wang, Y.; Zhang, J.; Wu, Y.; Yi, Z.; Chi, F.; Wang, H.; Li, W.; Zhang, Y.; Zhang, X.; Liu, L. Solution-processed bathocuproine cathode buffer layer towards efficient planar heterojunction perovskite solar cells. Semicond. Sci. Technol. 2019, 34, 075023. [CrossRef]

43. Luo, D.; Zhao, L.; Wu, J.; Hu, Q.; Zhang, Y.; Xu, Z.; Liu, Y.; Liu, T.; Chen, K.; Yang, W.; et al. Dual-source precursor approach for highly efficient inverted planar heterojunction perovskite solar cells. Adv. Mater. 2017, 29, 1604758. [CrossRef] [PubMed]

44. Zhao, D.; Zhu, Z.; Kuo, M.Y.; Chueh, C.C.; Jen, A.K.Y. Hexaazatrinaphthylene derivatives: Efficient electron-transporting materials with tunable energy levels for inverted perovskite solar cells. Angew. Chem. Int. Ed. 2016, 55, 8999-9003. [CrossRef] [PubMed]

45. Xue, Q.; Hu, Z.; Sun, C.; Chen, Z.; Huang, F.; Yip, H.L.; Cao, Y. Metallohalide perovskite-polymer composite film for hybrid planar heterojunction solar cells. RSC Adv. 2015, 5, 775-783. [CrossRef]

46. Xiao, M.; Huang, F.; Huang, W.; Dkhissi, Y.; Zhu, Y.; Etheridge, J.; Weale, A.G.; Bach, U.; Cheng, Y.B.; Spiccia, L. A fast depositioncrystallization procedure for highly efficient lead iodide perovskite thin-film solar cells. Angew. Chem. 2014, 126, 10056-10061. [CrossRef]

47. Karuppuswamy, P.; Hanmandluc, C.; Boopathic, K.M.; Perumale, P.; Liu, C.C.; Chen, Y.F.; Chang, Y.C.; Wang, P.; Lai, C.C.S.; Chu, C.W. Solution-processable electron transport layer for efficient hybrid perovskite solar cells beyond fullerenes. Sol. Energy Mater. Sol. Cells 2017, 169, 78-85. [CrossRef]

48. Zuo, L.; Guo, H.; de Quilettes, D.W.; Jariwala, S.; Marco, N.D.; Dong, S.; DeBlock, R.; Ginger, D.S.; Dunn, B.; Wang, M.; et al. Polymer-modified halide perovskite films for efficient and stable planar heterojunction solar cells. Sci. Adv. 2017, 3, e1700106. [CrossRef]

49. Jin, Z.W.; Wang, J.H. A trilayer architecture for polymer photoconductors. Appl. Phys. Lett. 2013, 102, 053304. [CrossRef] 